\title{
MANAGEMENT OF DIABETIC FOOT ULCER: A LITERATURE REVIEW
}

\author{
Angger Anugerah Hadi Sulistyo* \\ Insan Cendekia Husada School of Health Science, Bojonegoro 62111, Indonesia \\ *E-mail: angger.anugerah@gmail.com
}

\begin{abstract}
This article explores the effective management of diabetic foot ulcer. A literature review was conducted by analyzing scholar papers including systematic review, clinical and a randomized control trial published between 2000 to 2016 in the English language. Data were searched through CINAHL, PubMed, Proquest and Google Scholar. The keywords used were diabetic foot ulcer or diabetic foot ulcers or diabetic foot or neuropathic foot ulcer combined with assessment and treatment. There were two kinds of assessment used in diabetic foot ulcer which are risk assessment and wound assessment. The treatments that frequently used in diabetic foot ulcer are systemic treatment and local treatment. This literature review can be used as a guideline and literature for further experimental studies.
\end{abstract}

Keywords: diabetic foot ulcer, management of foot ulcer, assessment of foot ulcer, treatment of foot ulcer

\begin{abstract}
Abstrak
Manajemen Luka Kaki Diabetes: Tinjauan Literatur. Artikel ini dibuat dengan mencari sumber literatur dari manajemen luka kaki diabetes. Tujuan studi literatur ini adalah untuk mencari manajemen luka diabetes yang paling efektif. Studi literatur ini dibuat dengan melakukan analisis artikel-artikel ilmiah meliputi systematic review, clinical and a randomized control trial dalam bahasa inggris yang dipublikasikan pada tahun 2000 sampai 2016. Data didapatkan dengan mencari di beberapa database meliputi CINAHL, PubMed, Proquest and Google Scholar. Kata kunci pencarian data yaitu dengan menggunakan kata kunci diabetic foot ulcer or diabetic foot ulcers or diabetic foot or neuropathic foot ulcer combined with assessment and treatment. Pada studi literatur ini didapatkan 14 artikel yang sesuai dengan kriteria penelitian. Hasil pencarian artikel ditemukan 2 jenis pengkajian luka diabetes yaitu pengkajian resiko dan pengkajian luka diabetes. Sedangkan penanganan yang sering digunakan dalam luka diabetes adalah penanganan sistemik dan penaganan local. Studi literatur ini dapat dijadikan petunjuk dan tambahan referensi untuk penelitian experiment.
\end{abstract}

Kata Kunci: luka kaki diabetes, manajemen luka kaki, pengkajian luka kaki, penanganan luka kaki

\section{Introduction}

Diabetic Foot Ulcer (DFU) is the most devastating complication of Diabetes Mellitus (DM). DFU happens in a patient with diabetes that takes almost $25 \%$ of diabetic patients (Armstrong, Wrobel, \& Robbins, 2008). DFU leads lower extremity amputation during the course of disease around 14 to 24\% (Markowitz, Gutterman, Magee \& Margolis, 2006). In the United States, DFU led to 80.000 amputations per year (Aumiller \& Dollahite, 2015).

The emergence of DFU is the result of peripheral neuropathy, ischemia, and neuro-ische- mia. Loss of protective sensation and loss of coordination of feet muscle due to neuropathy impacts mechanical stresses during ambulation (Davies, Brophy, Williams, \& Taylor, 2006). In addition, decreased oxygen supply in lower limb creates ischemia and it also can cause an actual wound. DFU can be caused by the combination of ischemia and neuropathy which worsen patient's skin integrity.

DFU is a complication of DM that can be healed. Appropriate diet, activity and therapy adjustments can affect the DFU healing. Around 60-80\% DFU will heal. However, 10-15\% will remain germinate, and within a period of 
6-18 months, 5-24\% of them had an amputation (Alexiadou \& Doupis, 2012). A study conducted by Hayes et al (2017) states, more than $50 \%$ of DFU addressed the sign of healing with proper management of DFU.

Management in DFU consists of assessment and treatment. It covers both general conditions and site of ulcers. General assessment in patients with diabetes includes diabetes status, previous history of DFU, previous amputation, risk factor of DFU, symptoms of peripheral arterial disease and medication used (Harries \& Harding, 2015). Moreover, treatments in DFU consist of general treatment for diabetes status and in the site of wound. Appropriate management in site ulceration and systemic body metabolism become an important thing while treating DFU. Strategies to increase wound healing and prevent recurrence of DFU should be stressed on good glycemic control, foot care, diet and exercise (Vileikyte, 2001).

DFU has become a serious problem in worldwide and its management needs a multidisciplinary approach. These review purposes to present current evidence-based assessment and treatment strategies of DFU. The author believes that this review may be useful for nurse who involved in overall management of diabetic foot ulcer.

\section{Methods}

A comprehensive literature review according to management of diabetic foot ulcer was done

Table 1. Literature Review Summary

\begin{tabular}{|c|c|c|c|}
\hline Database & Keyword & $\begin{array}{c}\text { Articles } \\
\text { Found }\end{array}$ & $\begin{array}{c}\text { Relevant } \\
\text { Article }\end{array}$ \\
\hline CINAHL & $\begin{array}{l}\text { Diabetic-foot-ulcer OR diabetic-foot-ulcers OR diabetic foot } \\
\text { OR Neuropathic-foot-ulcer } \\
\text { Assessment }\end{array}$ & 64 & 1 \\
\hline ProQuest & $\begin{array}{l}\text { Diabetic-foot-ulcer OR diabetic-foot-ulcers OR diabetic foot } \\
\text { OR Neuropathic-foot-ulcer } \\
\text { Assessment }\end{array}$ & 93 & 2 \\
\hline PubMed & $\begin{array}{l}\text { Diabetic-foot-ulcer OR diabetic-foot-ulcers OR diabetic foot } \\
\text { OR Neuropathic-foot-ulcer } \\
\text { Assessment }\end{array}$ & 59 & 3 \\
\hline Google Scholar & $\begin{array}{l}\text { Diabetic-foot-ulcer OR diabetic-foot-ulcers OR diabetic foot } \\
\text { OR Neuropathic-foot-ulcer } \\
\text { Assessment }\end{array}$ & 108 & 2 \\
\hline CINAHL & $\begin{array}{l}\text { Diabetic-foot-ulcer OR diabetic-foot-ulcers OR diabetic foot } \\
\text { OR Neuropathic-foot-ulcer } \\
\text { Treatment }\end{array}$ & 78 & 3 \\
\hline ProQuest & $\begin{array}{l}\text { Diabetic-foot-ulcer OR diabetic-foot-ulcers OR diabetic foot } \\
\text { OR Neuropathic-foot-ulcer } \\
\text { Treatment }\end{array}$ & 88 & 0 \\
\hline PubMed & $\begin{array}{l}\text { Diabetic-foot-ulcer OR diabetic-foot-ulcers OR diabetic foot } \\
\text { OR Neuropathic-foot-ulcer } \\
\text { Treatment }\end{array}$ & 50 & 3 \\
\hline
\end{tabular}


by using electronic database. The following databases are Cinhal, Proquest, Google Scholar and Pubmed. Further review than done in relevant reference by scanned references that met inclusions criteria.

The inclusion criteria are: 1) systematic review, clinical and a randomized control trial published between 2000-2016; 2) full-length article; 3) population in diabetic foot ulcer; 4) English language. Exclusion criteria were: abstracts. In total, 540 articles regarding management of diabetic foot ulcer were found in this study. However, around 14 articles that were met with the criteria of this study (Table 1).

\section{Results}

In order to clarify quality of the result of this study, the articles were selected through the inclusion and exclusion criteria. Moreover, all articles in this study were from reputable journals.
Assessment Tool. In deep scholarly reviews found 8 assessment tools that frequently used. There were consisted of wound assessment and risk assessment tools. Although, some of the assessment tools not provide the validity and reliability data (Table 2 ).

Treatment of DFU. Treatments of DFU consist of local wound treatment (dressing, offloading, additional therapies) and systemic treatment (blood sugar control). Based on literature review author found current treatment of DFU consist of 6 RCTs and 2 systematic reviews (Table 3).

\section{Discussion}

Management of DFU. Diabetic foot ulcers have a high number of morbidity and until today they are still complex to manage. DFU have rapid progress and they can develop many complications that can threaten life and limb (Bentley \& Foster, 2008). It should take a proper

Table 2. Matrix Table for Assessment Tool

\begin{tabular}{|c|c|c|c|c|c|c|c|}
\hline Scoring System & $\begin{array}{c}\text { Number of } \\
\text { Classifications } \\
\text { or Size of Scale } \\
\end{array}$ & $\begin{array}{c}\text { Type Of } \\
\text { Assessment } \\
\text { Tool } \\
\end{array}$ & Area & Depth & Infection & Ischemia & Neuropathy \\
\hline PUSH tool & 3 variables & $\begin{array}{l}\text { Wound } \\
\text { assessment }\end{array}$ & $\checkmark$ & $\checkmark$ & $\checkmark$ & $\checkmark$ & - \\
\hline $\begin{array}{l}\text { Neuropathy Symptom } \\
\text { Score (NSS) }\end{array}$ & 4 variables & $\begin{array}{l}\text { Risk } \\
\text { assessment }\end{array}$ & - & - & - & $\checkmark$ & $\checkmark$ \\
\hline $\begin{array}{l}\text { Neuropathy } \\
\text { Disability Score } \\
\text { (NDS) }\end{array}$ & 4 variables & $\begin{array}{l}\text { Risk } \\
\text { assessment }\end{array}$ & - & - & - & $\checkmark$ & $\checkmark$ \\
\hline $\begin{array}{l}\text { Meggitt-Wagner } \\
\text { classification of foot } \\
\text { ulcers }\end{array}$ & $\begin{array}{l}0-5, \text { linear } \\
\text { grading }\end{array}$ & $\begin{array}{l}\text { Wound } \\
\text { assessment }\end{array}$ & $\checkmark$ & $\checkmark$ & $\checkmark$ & $\checkmark$ & - \\
\hline $\begin{array}{l}\text { Diabetic Neuropathy } \\
\text { Symptoms (DNS) }\end{array}$ & 4 variables & $\begin{array}{l}\text { Risk } \\
\text { assessment }\end{array}$ & - & - & - & $\checkmark$ & $\checkmark$ \\
\hline PEDIS score & 5 variables & $\begin{array}{l}\text { Wound } \\
\text { assessment }\end{array}$ & $\checkmark$ & $\checkmark$ & $\checkmark$ & $\checkmark$ & $\checkmark$ \\
\hline $\begin{array}{l}\text { UT wound } \\
\text { classification systems }\end{array}$ & $\begin{array}{l}0-3, \text { linear } \\
\text { grading }\end{array}$ & $\begin{array}{l}\text { Wound } \\
\text { assessment }\end{array}$ & $\checkmark$ & $\checkmark$ & $\checkmark$ & $\checkmark$ & $\checkmark$ \\
\hline $\mathrm{S}(\mathrm{AD})$ & $\begin{array}{l}0-3 \text { linear } \\
\text { grading }\end{array}$ & $\begin{array}{l}\text { Wound } \\
\text { assessment }\end{array}$ & $\checkmark$ & $\checkmark$ & $\checkmark$ & $\checkmark$ & $\checkmark$ \\
\hline
\end{tabular}


Table 3. Matrix Table for DFU Treatment

\begin{tabular}{|c|c|c|c|c|c|c|c|}
\hline Author(s) & Intervention & Control & $\begin{array}{l}\text { Type } \\
\text { of } \\
\text { study }\end{array}$ & Sample & Country & $\begin{array}{l}\text { Standard wound } \\
\text { care }\end{array}$ & Conclusions \\
\hline $\begin{array}{l}\text { Lavery, et } \\
\text { al. }(2015)\end{array}$ & $\begin{array}{l}\text { Healing } \\
\text { sandals; Total } \\
\text { contact cast; } \\
\text { Shear walker }\end{array}$ & - & $\mathrm{RCT}$ & $\begin{array}{l}\text { Healing } \\
\text { sandals, } n=23 \text {; } \\
\text { Total contact } \\
\text { cast, } n=23 ; \\
\text { Shear } \\
\text { walker, } n=27\end{array}$ & USA & $\begin{array}{l}\text { Wounds were } \\
\text { dressed with } \\
\text { hydrogel and } \\
\text { covered with a } \\
\text { single layer of } \\
\text { fine mesh gauze }\end{array}$ & $\begin{array}{l}\text { TCC better than } \\
\text { another regarding } \\
\text { Wound healing in } \\
12 \text { weeks and } \\
\text { healing time }\end{array}$ \\
\hline $\begin{array}{l}\text { Kamaratos } \\
\text { et al. } \\
(2014)\end{array}$ & $\begin{array}{l}\text { Medihoney } \\
\text { Tulle Dressing }\end{array}$ & $\begin{array}{l}\text { Conventio } \\
\text { nal } \\
\text { dressing }\end{array}$ & $\mathrm{RCT}$ & $\begin{array}{l}\text { MHID } n=32 \\
\text { Conventional } \\
\text { dressing } n=31\end{array}$ & Greece & $\begin{array}{l}\mathrm{CD} \text {, saline- } \\
\text { soaked gauze } \\
\text { dressings }\end{array}$ & $\begin{array}{l}\text { MHID increased } \\
\text { mean healing time } \\
\text { Keep wound } \\
\text { sterile condition } \\
\text { longer }\end{array}$ \\
\hline $\begin{array}{l}\text { Jeffcoate, } \\
\text { et al. } \\
(2009)\end{array}$ & $\begin{array}{l}\text { 1.Fibrous- } \\
\text { hydrocolloid } \\
\text { (hydrofibre) } \\
\text { dressing } \\
\text { (Aquacel) } \\
\text { 2.Iodine- } \\
\text { impregnated } \\
\text { dressing } \\
\text { (Inadine) } \\
\text { 3. Non-adherent } \\
\text { dressing, } \\
\text { viscose } \\
\text { filament } \\
\text { gauze (N-A) }\end{array}$ & - & $\mathrm{RCT}$ & $\begin{array}{l}\text { Aquacel: } 103 \\
\text { Inadine : } 108 \\
\text { N-A: } 106\end{array}$ & UK & $\begin{array}{l}\text { Dressings were } \\
\text { changed daily, on } \\
\text { alternate days or } \\
3 \text { times a week }\end{array}$ & $\begin{array}{l}\text { Inadine } 29.6 \% \text {, } \\
\text { Aquacel } 28.2 \% \\
\text { and N-A } 25.5 \% \\
\text { paitents healed by } \\
12 \text { weeks }\end{array}$ \\
\hline $\begin{array}{l}\text { Shaked, et } \\
\text { al. (2015) }\end{array}$ & $\begin{array}{l}\text { Transient cycles } \\
\text { of Ischemic } \\
\text { preconditioning } \\
\text { (IPC) }\end{array}$ & $\begin{array}{l}\text { Sham } \\
\text { procedure }\end{array}$ & $\mathrm{RCT}$ & $\begin{array}{l}\text { Group I }(\mathrm{n}= \\
24) \text { study } \\
\text { group } \\
\text { Group II }(\mathrm{n}= \\
\text { 16) control } \\
\text { group }\end{array}$ & Israel & NS & $\begin{array}{l}\text { The ratio of } \\
\text { patients who } \\
\text { reached complete } \\
\text { healing of their } \\
\text { ulcer was } 9 / 22 \\
(41 \%) \text { in the study } \\
\text { group compared } \\
\text { with } 0 / 12(0 \%) \text { in } \\
\text { the control group }\end{array}$ \\
\hline $\begin{array}{l}\text { Mohajeri, } \\
\text { et al. } \\
(2014)\end{array}$ & $\begin{array}{l}\text { Ulcers were } \\
\text { dressed with } \\
\text { pure extract of } \\
\text { kiwifruit }\end{array}$ & $\begin{array}{l}\text { Standard } \\
\text { treatment }\end{array}$ & RCT & $\begin{array}{l}\text { Group I }(\mathrm{n}= \\
\text { 17) study } \\
\text { group } \\
\text { Group II }(\mathrm{n}= \\
\text { 37) control } \\
\text { group }\end{array}$ & Iran & $\begin{array}{l}\text { Sterile ulcer } \\
\text { dressing with } \\
\text { sterile normal } \\
\text { saline; wound } \\
\text { dressing change } \\
\text { thrice a day }\end{array}$ & $\begin{array}{l}\text { Ulcer size and } \\
\text { wound closure in } \\
\text { intervention group } \\
\text { are significant } \\
\text { different with } \\
\text { control group. }\end{array}$ \\
\hline $\begin{array}{l}\text { Zang, et } \\
\text { al. (2014) }\end{array}$ & $\begin{array}{l}\text { Standard } \\
\text { treatment plus } \\
\text { oxygen-ozone } \\
\text { treatments }\end{array}$ & $\begin{array}{l}\text { Standard } \\
\text { treatment }\end{array}$ & RCT & $\begin{array}{l}\text { Group I }(\mathrm{n}= \\
25) \text { study } \\
\text { group } \\
\text { Group II }(\mathrm{n}= \\
25) \text { control } \\
\text { group }\end{array}$ & China & $\begin{array}{l}\text { Debridement } \\
\text { once every two } \\
\text { days and wound } \\
\text { dressings } \\
\text { appropriate for } \\
\text { the degree of } \\
\text { exudate and } \\
\text { moisture } \\
\text { maintenance of } \\
\text { the wound. }\end{array}$ & $\begin{array}{l}\text { The effective rate } \\
\text { was significantly } \\
\text { higher in ozone } \\
\text { group than in } \\
\text { control group }\end{array}$ \\
\hline
\end{tabular}


assessment and management to reduce further impacts of this disease. Based on literature review, there are several articles related to current assessment and treatment of DFU.

Assessment of DFU. Nowadays, the number of complication in diabetes involving DFU is high. However general practitioners tend to ignore assess diabetic patient regarding its complication. Less than $50 \%$ of diabetic patients reported that they received proper assessment according to DFU (Bowering, 2001). Based on literature there are two kinds of assessment for DFU: risk assessment and wound assessment. Literature review founds 8 assessment tools that frequently used (Table 2).

Risk Assessment. Several assessment tools have been developed to measure risk factor of DFU regarding neuropathy.

Neuropathic assessment. Several articles mentioned that Neuropathy Symptom Score (NSS) has proven valid and sensitive tool to assess neuropathy (Asad, et al, 2009; Alexiadou \& Doupis, 2012). NSS tool assess foot according to sensation, whether both feet can determine burn, tingling, pain and locate its location. NSS consist of seventeen items which focus on sensory disturbances, muscle weakness, and autonomic symptoms. However, NSS reported was too complex to apply in daily general practices. One comparative study tries to compare effectiveness NNS with Diabetic Neuropathy Symptoms (DNS). DNS consists of some following items which is simpler. DNS score each item from 0 which represents absence of neuropathy symptoms to maximum score 4 points which represent severe neuropathy. This tool assesses about (1) walking ability, (2) pain sensation or arching on feet, (3) prickling sensations, and (4) numbness in legs or feet (Meijer, et al., 2002).

Although NSS was widely used and proven, DNS also showed a significant correlation (Spearman $r$ ) with NSS. Therefore, DNS also has high sensitivity and specificity for evaluating neuropathy (Meijer, et al., 2002).
Circulatory assessment. Doppler ultrasonography can be used to measure Ankle Brachial Index (ABI) and it is widely used to determine blood flow of peripheral artery. However, ABI might result in false positive in diabetic patients, especially in diabetic patient because artificial high systolic pressure of ankle in diabetic patient is common due to calcification of the media distal arteries and it causes vessel relatively incompressible. However, the use of ABI with Doppler ultrasonography could use for early detection and it might reduce limb complications (Ikem, Ikem, Adebayo, \& Soyoye, 2010).

Wound Assessment. General practitioners including nurses have to monitor DFU progress to evaluate whether specific intervention is effective or is not. Some tools developed to measure wound healing in DFU.

PUSH tool (Pressure Ulcer Scale for Healing). PUSH tool which developed by (NPUAP) National Pressure Ulcer Advisory Panel actually creates in purpose to monitor progress of wound healing in pressure ulcer. Nowadays this tool has been validated and used for monitoring pressure ulcer as well as venous ulcer healing. However, current prospective study tries to use PUSH tool to monitor DFU (Gardner, Hillis, \& Frantz, 2011).

PUSH tool consists of three domains: length $x$ width, exudate amount, and tissue type. Length $\mathrm{x}$ width, centimeter ruler used to measure length and width (side to side). This tool also measures pus quantity with none, light, moderate, or heavy during wound dressing. Gardner, et al. (2011) examined whether PUSH tool valid or not to predict healing in DFU. The re-sult showed PUSH tool score of 10 would be expected wound to be healed in 8.8 weeks and PUSH score of 4 in 2.6 weeks.

Size (Area and Depth), Sepsis, Arteriopathy, and Denervation [S(AD)SAD]. SAD is consist of 5 items (area, depth, infection, ischemia and neuropathy), which each item subcategorized $0-3$. That entire item has great specificity in 
DFU description. However, some authors mention this tool shows nonregular in structure so it makes harder to remember (Abbas, et al., 2008).

Wegner score. The purpose of Wagner system is to assess the depth of ulcer and the presence of gangrene or osteomyelitis. This tool consist of 0-5 linear grading (grade 0 (pre-or postulcerative lesion), grade 1 (partial/full thickness ulcer), grade 2 (probing to tendon or capsule), grade 3 (deep with osteitis), grade 4 (partial foot gangrene), and grade 5 (whole foot gangrene). Wagner is the most frequent tool to measure the development of the wound because this tool is easy to apply and reliable. One study showed positive trend of Wegner score to predict increased number of amputation. Wegner score can be used as a tool to monitor wound development (Karthikesalingam, et al., 2010).

University of Texas wound classification systems (UT system). The purpose of UT system is to measures the depth of ulcer, presence of wound infection, and presence of symptoms of lower-extremity ischemia. UT system consists of $0-3$ linear grading. Grade 0 pre or postulcerative that healed, grade 1 only showed superficial ulcer, grade 2 ulcer penetrate to tendon and grade 3 ulcer penetrate to bone and joint. Moreover there are four stages within each wound grade: stage A is cleans wound, stage $\mathrm{B}$ is infected wounds but still nonischemic, stage $\mathrm{C}$ is already developed ischemic but wounds still non-infected, stage $\mathrm{D}$ is infected and ischemic wounds.

\section{Treatment}

Systemic Treatment. The important treatment of patients with DFU is to control diabetes systematically. Nutritional management and blood sugar control are very influential for the patient's recovery.

Blood Sugar Control. Historically, inadequate blood sugar control can induce foot ulcer due to limb neuropathy. Currently, no studies de- veloped in human to determine whether blood sugar control have benefit for foot ulcer. However, studies in animal showed hyperglycemia impairs wound healing. So, keeps blood sugar in reasonable level can improve healing.

Nutrition to Promote Wound Healing. Chronic wound needs a lot of resources in daily routines to promote wound healing including nutritional support. Nutritional support is essential in DFU, it is due to during wound healing process tissue demand more energy. Energy and protein usually become main resources for building a new cell. Therefore, undernourished and malnourished patients can be very challenging to take concern (Wild, et al., 2010).

Patients is unique and different with each other, therefore clinical significant of nutrition and wound healing also individually different. However, general practitioners must decide what, when and how nutritional supplementation needs. A systematic review by Wild et al (2010) described macro and micronutrients that can improve wound healing. There are 5 main nutrients which can improve wound healing: (1) protein supply is necessary because it relate with synthesis collagen the production of fibroblast, (2) fatty acids are substrate of eicosanoid synthesis and one of cell membranes components which promotes inflammatory phase, (3) vitamin $\mathrm{C}$ is important for optimizing immune response, cell mitosis and monocyte migration to wound tissue that changed into macrophages during inflammatory process, (4) zinc becomes cofactor for some enzyme and it is involved RNA, DNA and proteins synthesis, (5) iron becomes cofactor some enzymes which are important for synthesis of collagen (Wild et.al., 2010).

\section{Local treatment}

Dressing. There are lots of types of dressing which used in DFU. However, dressings usually tend to apply by general practitioners based on professional experiences or preference more than based on evidence-based studies. Therefore the study developed in UK tries to 
compare the effectiveness of three common dressing used in UK. This study compared the efficacy of fibrous-hydrocolloid (aquacel) dressing, iodine-impregnated dressing (Inadine), nonadherent dressing, viscose filament gauze (NA). Involved 317 participants, this RCT studies selected respondents by inclusion and exclusion criteria and divided into three groups. All of groups have same treatment except the dressing. Dressing changed applies daily or 3 times a week used current guidelines for practice including debridement and offloading. The result showed that, after 12 weeks N-A $25.5 \%$, Aquacel $28.2 \%$, and Inadine $29.6 \%$ of patients present healing. So for this result Inadine which is iodine-impregnated dressing proved become dressing product that most improved DFU healing (Jeffcoate et al., 2009).

Not only modern dressing, alternatives dressing used natural product also found effective to improve wound healing. A Prospective RCT, double-blinded study used Manuka honeyimpregnated dressing in the treatment of neuropathic diabetic foot ulcers. Thirty-two participants in treatment group treated by MHID (Medihoney Tulle Dressing) and another thirtyone treated with conventional dressing. Preparation and wound care were applied by staff nurses in a daily basis. Participants follow 16 weeks intervention whether treatment group and control group. The result showed that mean healing time significantly differences between 2 groups ( $p<0.05$ ). Moreover, $78 \%$ participants in treatment group presented sterile ulcers in $1^{\text {st }}$ week of follow up and in control group only showed 35\% participants showed sterile wound in $1^{\text {st }}$ week of follow up (Kamaratos, et al., 2014). Therefore, Manuka honey-impregnated dressing is safe and proved to improve wound healing time. Moreover, it keeps the wound in sterile condition longer than conventional dressing.

One study in Iran by Mohajeri, et al. (2014) conducted study about effectiveness pure extract kiwi fruit dressing to improve DFU healing. 54 respondents were assigned into two group, 17 respondents in study group and 37 in control group. Both of study group and control group received same standard treatments (regular sterile dressing with normal saline, surgical debridement, oral antibiotic and blood sugar control). The result showed study group can improve wound healing in terms of ulcer size and wound closure. Study group showed significant differences with the control group in both ulcer size and wound closure.

Ischemic Preconditioning (IPC). Performing IPC in healthy patients proved to demonstrate augmentation potential of blood endothelial progenitor cells. Moreover, IPC showed mobilized stem cell which improved number of peripheral blood stem cells. RCT conducted in Israel revealed that IPC became effective to improve wound healing. Forty participants followed this study and they were divided into 2 group: IPC group and sham group. All participants receive standard wound care delivered by staff of clinic. Pressure cuffs applied in both arms and inflated and deflated 3 cycles of 5 minutes each. The pressure was different between both groups. In IPC group cuffs inflated $200 \mathrm{mmHg}$, in another hand, the sham procedure only gave $10 \mathrm{mmHg}$. All participant followed 6-week intervention and examined every 2 weeks. The result showed significant differences between 2 group. A number of $41 \%$ participants in IPC group reached complete healing in 6 weeks. On the other hand, there are no participants reached complete healing in 6 weeks (Shaked, et al., 2015).

Oxygen-ozone Treatments. Oxygenation is important for wound in order to improve healing outcome. In DFU, tissue hypoxia due to lack of peripheral oxygenation is noted in problem of wounds. Ulcer tissue oxygenation is essential and might be influenced healing outcome.

RCT conducted in China by Zhang, et al. (2014) showed that oxygen-ozone treatment improved wound healing and increase collagen fibers of the wound. The study group of this 
research received standard treatment which same as control group. After debridement, respondents in study group received noninvasive oxygen-ozone treatments 30 minutes for 20 days. The oxygen supplied by using the ozone generator device with $52 \mu \mathrm{g} / \mathrm{mL}$ ozone in a special bag. After 20 days intervention, the study group showed significant wound healing compare with control group. Moreover, oxygen-ozone treatment also increased collagen fibers in site of wound.

Offloading. Lower limb neuropathies lead to development of foot shear or broken skin. It is due to increased pressure in the same site of the plantar foot and neglected by diabetic patients. In concept of management of DFU, offload plantar foot from frequent pressure is important to prevent foot shear. Offloading nowadays is widely used because of some study proved the efficacy of offloading help to promote wound healing. A systematic review of management of DFU mentioned that elevated pressure of plantar foot significantly improved foot ulcer. Total Contact Cast (TCC) was claimed to be the most effective method of offloading currently (Alexiadou \& Doupis, 2012).

Moreover, some study compared the effectiveness of TCC compare with another method. One RCT examined the efficacy of TCC, removable boot with a shear-reducing footbed (SRB) and healing sandal (HSS). Total 73 participants divided into three groups and received treatment within 12 weeks. The result proved that TCC became the most effective offloading method according to proportion of wound healing and fastest healing time (Lavery, et al., 2015).

\section{Conclusion}

Diabetes foot ulcer is one of serious complication in diabetes and its incidence is rapidly increased. Appropriate management of each factor believed can reduce the incidence of foot ulcer. However, some factors like age and duration of DM are not modifiable so patients and nurses should be concerned about that condition.

The management of DFU consists of assessment and treatment that become comprehensive approach in patients with DFU. Comprehensive DFU assessments concerned on risk and recurrence assessment and wound site assessment. Based on literature review, eight assessment tools found that are NSS, Circulatory assessment and PUSH tool, Wegner, UT system and SAD. All of them are important to measure the possibility diabetic patients develop DFU and measure the efficacy of some intervention according to wound healing. However, only three tools that showed reliability: PUSH tool (0.96), NSS (0.74) and DNS (0.64). Need more study and review to determine the best instrument tools to assess DFU. Careful inspection and physical examination include neuropathy and vascular test are essential to notice "foot at risk".

The treatments of DFU are essential to prevent further deterioration of ulceration. Amputation, morbidity and mortality rates associated with DFU are the common incidents that have to treat with proper treatment. Blood sugar control, nutrition and offloading are kind of treatment which treat DFU systemically. However, local treatment in site of ulcer also important to prevent infection and promote wound granulation. Nurses have important role to determine whether treatments are proper for DFU or not. Recommendation for further literature review is to search in deep the latest research related comprehensive treatment of DFU. Especially research related to systematic treatment in DFU such as exercise, nutritional support, and blood sugar control (BY, AW, TN).

\section{Reference}

Abbas, Z.G., Lutale, J.K., Game, F.L., \& Jeffcoate, W.J. (2008). Comparison of four systems of classification of diabetic foot ulcers in 
Tanzania. Diabetic Medicine, 25 (2), 134 137.

Alexiadou, K., \& Doupis, J. (2012). Management of diabetic foot ulcers. Diabetes Therapy, 3(1), 4.

Armstrong, D.G., Wrobel, J., \& Robbins, J.M. (2008). Guest Editorial: Are diabetesrelated wounds and amputations worse than cancer? International wound journal, (4), 286-287.

Asad, A., Hameed, M.A., Khan, U.A., Butt, M.R. A., Ahmed, N., \& Nadeem, A. (2009). Comparison of nerve conduction studies with diabetic neuropathy symptom score and diabetic neuropathy examination score in type-2 diabetics for detection of sensorimotor polyneuropathy. The Journal of the Pakistan Medical Association, 59 (9), 594.

Aumiller, W.D., \& Dollahite, H.A. (2015). Pathogenesis and management of diabetic foot ulcers. Journal of the American Academy of Physician Assistants, 28 (5), 28-34.

Bentley, J., \& Foster, A. (2008). Management of the diabetic foot ulcer: Exercising control. British journal of community nursing, 13 (3).

Bowering, C.K. (2001). Diabetic foot ulcers. Pathophysiology, assessment, and therapy. Canadian Family Physician, 47(5), 10071016.

Davies, M., Brophy, S., Williams, R., \& Taylor, A. (2006). The prevalence, severity, and impact of painful diabetic peripheral neuropathy in type 2 diabetes. Diabetes Care, 1518-1522.

Gardner, S.E., Hillis, S.L., \& Frantz, R.A. (2009). Clinical signs of infection in diabetic foot ulcers with high microbial load. Biological Research for Nursing, 11 (2), 119-128. http://doi.org/10.1177/1099800408326169.

Gardner, S.E., Hillis, S.L., \& Frantz, R.A. (2011). A prospective study of the PUSH tool in diabetic foot ulcers. Journal of wound, ostomy, and continence nursing: official publication of The Wound, Ostomy and Continence Nurses Society/WOCN, 38 (4), 385.

Harries, R.L., \& Harding, K.G. (2015). Management of Diabetic Foot Ulcers. Current Geriatrics Reports, 4 (3), 265 276.

Hayes, P.D., Alzuhir, N., Curran, G., \& Loftus, I. M. (2017). Topical oxygen therapy promotes the healing of chronic diabetic foot ulcers: a pilot study. Journal of wound care, 26 (11), 652-660.

Ikem, R., Ikem, I., Adebayo, O., \& Soyoye, D. (2010). An assessment of peripheral vascular disease in patients with diabetic foot ulcer. The Foot, 20 (4), 114-117.

Jeffcoate, W.J., Price, P.E., Phillips, C.J., Game, F.L., Mudge, E.J., Davies, S., ... Jones, G.R. (2009). Randomised controlled trial of the use of three dressing preparations in the management of chronic ulceration of the foot in diabetes. Health technology assessment, 13 (54), 1-124.

Kamaratos, A.V., Tzirogiannis, K.N., Iraklianou, S.A., Panoutsopoulos, G.I., Kanellos, I.E., \& Melidonis, A.I. (2014). Manuka honey-impregnated dressings in the treatment of neuropathic diabetic foot ulcers. International wound journal, 11 (3), 259-263.

Karthikesalingam, A., Holt, P.J.E., Moxey, P., Jones, K.G., Thompson, M.M., \& Hinchliffe, R.J. (2010). A systematic review of scoring systems for diabetic foot ulcers. Diabetic Medicine, 27 (5), 544549 .

Laing, P. (1994). Diabetic foot ulcers. The American journal of surgery, 167 (1), S31-S36.

Lavery, L.A., Higgins, K.R., La Fontaine, J., Zamorano, R.G., Constantinides, G.P., \& Kim, P.J. (2015). Randomised clinical trial to compare total contact casts, healing 
sandals and a shear-reducing removable boot to heal diabetic foot ulcers. International Wound Journal, 12 (6), 710-715.

Markowitz, J.S., Gutterman, E.M., Magee, G., \& Margolis, D.J. (2006). Risk of amputation in patients with diabetic foot ulcers: a claims-based study. Wound repair and regeneration, 14 (1), 11-17.

Meijer, J.W. G., Smit, A.J., Sonderen, E.V., Groothoff, J.W., Eisma, W.H., \& Links, T. P. (2002). Symptom scoring systems to diagnose distal polyneuropathy in diabetes: the Diabetic Neuropathy Symptom score.Diabetic Medicine, 19 (11), 962965.

Mohajeri, G., Safaee, M., \& Sanei, M.H. (2014). Effects of topical Kiwifruit on healing of neuropathic diabetic foot ulcer. Journal of Research in Medical Sciences: The Official Journal of Isfahan University of Medical Sciences, 19 (6), 520.

Oyibo, S.O., Jude, E.B., Tarawneh, I., Nguyen, H.C., Harkless, L.B., \& Boulton, A.J. (2001). A comparison of two diabetic foot ulcer classification systems the Wagner and the University of Texas wound classification systems. Diabetes care, 24 (1), 84-88.

Shaked, G., Czeiger, D., Abu Arar, A., Katz, T., Harman-Boehm, I., \& Sebbag, G. (2015). Intermittent cycles of remote ischemic preconditioning augment diabetic foot ulcer healing. Wound Repair and Regeneration, 23 (2), 191-196.

Vileikyte, L. (2001). Diabetic foot ulcers: a quality of life issue.Diabetes/metabolism research and reviews, 17 (4), 246-249.

Wild, T., Rahbarnia, A., Kellner, M., Sobotka, L., \& Eberlein, T. (2010). Basics in nutrition and wound healing. Nutrition, 26 (9), 862 866.

Zhang, J., Guan, M., Xie, C., Luo, X., Zhang, Q., \& Xue, Y. (2014). Increased growth factors play a role in wound healing promoted by noninvasive oxygen-ozone therapy in diabetic patients with foot ulcers. Oxidative medicine and cellular longevity, 2014. 